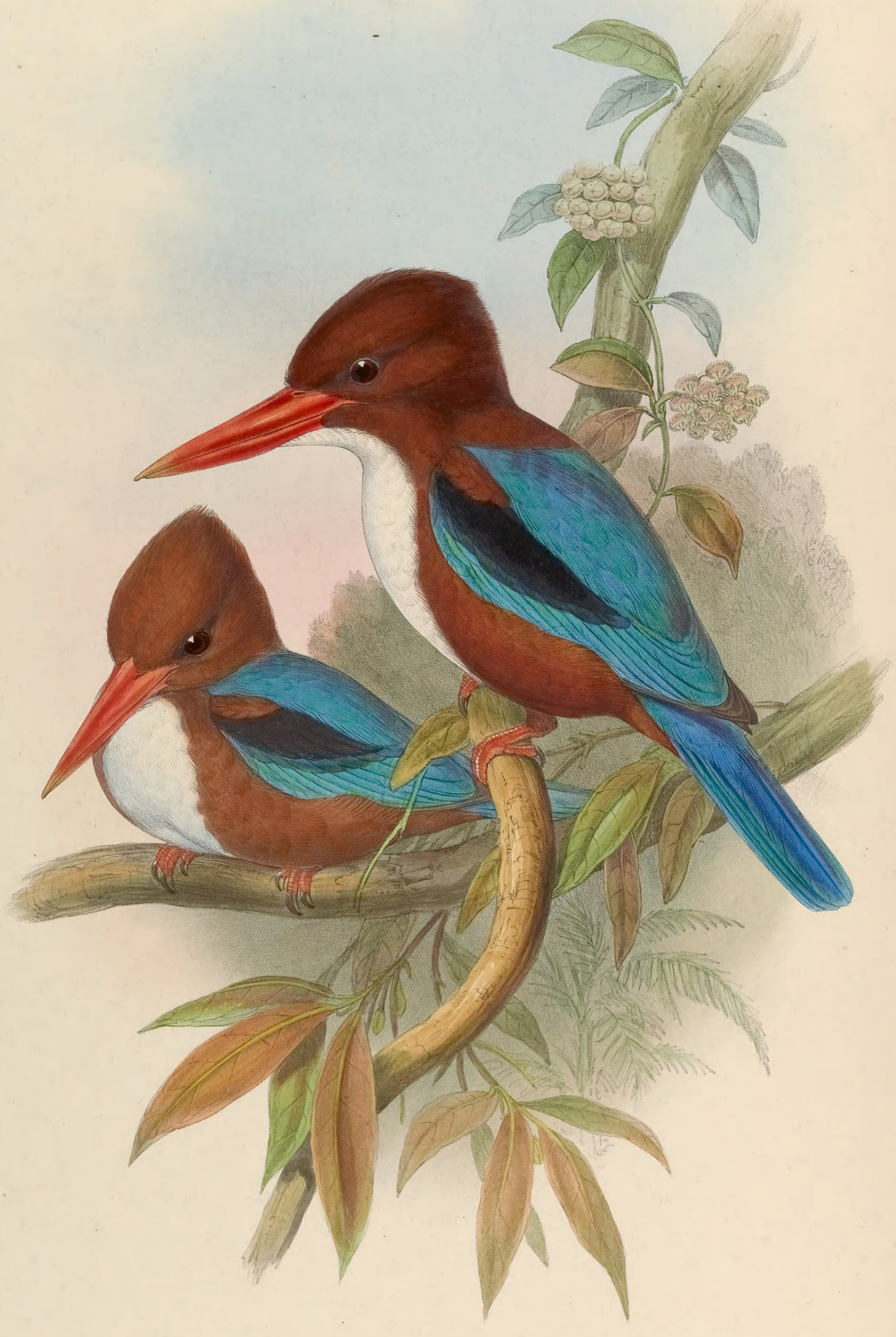




\section{HALCYON FUSCA.}

\section{Indian Kingfisher.}

Martin-pécheur de la côte de Malabar, Buff. Pl. Enl., 894.

Alcedo fusca, Bodd. Tabl. Pl. Enl., p. 51. t. 894

myrnensis var. $\gamma$, Gmel. edit. Linn. Syst. Nat., tom. i. p. 457.-Lath. Ind. Orn., vol. i. p. 248.-Vieill. Encyc. Méth. part i. p. 286, var. $\alpha$.

Dacelo smyrnensis, Less. Traité d'Orn., p. 246.-Sykes, Proc. of Comm. of Sci. and Corr. of Zool. Soc., part ii. p. 84.-McClell. in Proc. of Zool. Soc., part vii. p. 156.-Jerd. Madras Journ. Lit. and Sci. 1840, p. 230.-Pears. Journ. Asiat. Soc. Beng. 1841, p. 633.-Gray, Cat. of Spec. and Draw. of Mamm. and Birds presented to Brit. Mus. by B. H. Hodgson, Esq., p. 47

Halcyon fusca, Gray and Mitch. Gen. of Birds, vol. i. p. 79, Halcyon, sp. 12.-Gray, List of Birds in Coll. Brit. Mus., part ii. p. 55.-Bonap. Consp. Gen. Av., p. 155, Halcyon, sp. 23.-Cass. Cat. of Halc. in Coll. Acad. Sci. Philad., p. 8. sp. 3.-Horsf. and Moore, Cat. of Birds in Mus. E. I. Comp., vol. i. p. 125. Entomothera fusca, Reich. Handb., i. p. 12. 32. t. 404. 3088-89.

Alcedo erythrorhyncha, Licht. in Mus. Berol.

Entomobia fusca, Cab. Mus. Hein., Theil ii. p. 155.

Halcyon Smyrnensis, Blyth, Cat. of Birds in Mus. Asiat. Soc. Calcutta, p. 47.-Layard in Ann. and Mag. Nat. Hist., vol. xii. 2nd ser. p. 172.-Burgess in Proc. of Zool. Soc., part xxiii. p. 28.

Kilkila of the Hindoos, Jerdon.

Sada-bak Match-ranga of the Bengalese, Blyth, and Dr. F. B. Hamilton.

Matsya-ranga, in Sanscrit, Wilson.

Calavy Cooroovi, Mal. ; lit. Large-mouthed Bird Layard.

Some ornithologists are of opinion that the Halcyon of Asia Minor is specifically distinct from the one figured on the accompanying Plate, which is so very generally distributed over the whole of India that it has had the trivial name of the Indian Kingfisher bestowed upon it. Now the only differences which I am able to detect between it and the Smyrna bird, are a slight variation in size and in brilliancy of colouring, the Indian species being somewhat smaller and more intense and beautiful in colour.

The Halcyon fusca is found in all parts of the Indian Peninsula, Assam, Aracan, Tenasserim, and Ceylon ; and I have also seen specimens from Siam.

Captain Burgess informs us that " this Kingfisher is one of the most common of its tribe in the Deccan, frequenting almost every stream and nullah. It breeds during the month of May, in holes of the banks of rivers, laying as many as seven eggs, of a beautiful pinky tinge, owing to the colour of the yelk showing through the thin delicate shell."

"This," says Mr. Jerdon, "is the most common and generally spread of the Indian Kingfishers, frequenting not only the rivers and brooks, tanks, wells, and wet paddy-fields, but also dry cultivated ground, groves, old walls, and many other similar situations. It preys upon small fish (which it pursues below the surface), frogs, tadpoles, and various water insects; also on small lizards, grasshoppers, and various other large insects. It has a very loud, harsh, rattling scream, generally uttered during flight. Is said to breed in holes on the banks of rivers."

Mr. Layard states that in Ceylon this bird is "very common and widely distributed, feeding indiscriminately on fresh- or salt-water fish, crabs, beetles, and butterflies. I have seen them capture these last in the manner of Flycatchers (Muscicapide), darting from a sprig, and seizing them in the air, their mandibles closing with a snap, audible at the distance of some yards. One, which was unluckily introduced into an aviary, destroved most of the lesser captives ere he was detected as the culprit; he was at last caught in the act of seizing a small bird in his powerful bill; he beat it for a moment against his perch, and then swallowed it whole. The nest of this species is found in decaying trees; the parent bird deposits two white eggs (axis 15 lines, diam. 13 lines), beautifully smooth and shining. I have procured eggs in the north of the island in December, in the south in April."

Head, cheeks, sides and back of the neck, edges of the shoulders, under coverts of the wing, flanks, abdomen, vent, under tail-coverts and thighs dark chestnut-brown ; centre of the back and scapularies dull green washed with verditer blue; lower part of the back and upper tail-coverts fine verditer blue; greater wing-coverts black, the lowermost row tipped with deep green; spurious wing green ; basal portion of the outer webs of the primaries pale green, passing into deeper green, basal portion of their inner webs white; the apical half of both webs deep black; secondaries bluish green on their external webs, black on the inner ; tail deep green, glossed with blue above, brownish black beneath; chin, throat, and centre of the breast white; irides hazel; bill, legs, and feet deep orange-red.

The Plate is intended to represent both sexes of the size of life; it will be seen, therefore, that they do not differ in their colouring. The climbing plant is the Otostemma lacunosa. 


\section{$2 \mathrm{BHL}$ Biodiversity Heritage Library}

Gould, John. 1861. "Indian Kingfisher, Halcyon fusca [PI. 43]." The Birds of Asia 1(XIII), -. https://doi.org/10.5962/p.323347.

View This Item Online: https://www.biodiversitylibrary.org/item/115342

DOI: https://doi.org/10.5962/p.323347

Permalink: https://www.biodiversitylibrary.org/partpdf/323347

\section{Holding Institution}

Smithsonian Libraries

\section{Sponsored by}

Smithsonian Institution Libraries

\section{Copyright \& Reuse}

Copyright Status: Not in copyright

This document was created from content at the Biodiversity Heritage Library, the world's largest open access digital library for biodiversity literature and archives. Visit BHL at https://www.biodiversitylibrary.org. 